division takes a second one of the fire methods, and so on till each has had them all. Lecture and laboratory exercise have helped each other. Each one understanos the subject and is prepared to enjoy and profit by the more careful measurement of specific gravity with delicate balance and corrections for variation of temperature and pressure from standard conditions, that awaits him in his term or two of advanced practical work. Such a course prepares him fully for the higher grade of work, so that neither inherent difficulties or imperfect explanation can now be a bar to progress.

It must be admitted that the method presented involves some additional effort. on the part of the instructor, but there is abundant compensation in the superior results obtained. If space permitted, I would add something concerning methods of securing at small expense the duplication of apparatus necessary to keep the laboratory studies in close connection with lecture and classroom work, but that would better be reserved for another occasion.

\section{DISCOVERY OF ANCIENT ARGILLITE QUARRIES ON THE DELAWARE.}

BY HENRY C. MERCER, DOYLESTOWN, PA.

The discussion of the Trenton gravel specimens has forced several important questions upon our attention. Where did the argillite come from with which the chipped objects were made? Granted that much of it was found in the river-bed in the shape of boulders and erratic blocks, whence had this material been transported by the river?

To learn that modern Indians on the Delaware quarried jasper and in the process of blade-making strewed the quarry site with "wasters," resembling in form the Trenton specimens, was to ask whether they also quarried argillite.

We had found argillite "turtle-backs" on the surface at the camp-sites of Gilmer's Island, Gallows Run, Ridges Island, and Lower Black's Eddy on the Delaware, but they lacked the final and convincing association with the quarry to prove their pedigree, and we still sought the whereabouts of the ancient pits, the refuse heaps, and the "rejects" or blocked-out implements which were to repeat in the now famous blue stone, the story of the inchoate blades of jasper.

The way towards an answer to one of the vital questions that concerns the antiquity of man in the Delaware valley was opened on May 22, by the discovery by me of a series of seven or eight depressions surrounded by masses of argillite chips (a quarry in fact with all the surface characteristics of Macungie, Vera Cruz, and Durham, in America, or Grimes Graves, or Spiennes, in Europe) on the steep north slope of the hillside at Point Pleasant, Bucks County, Pennsylvania, on the right bank of Gaddis' Run, about one-quarter mile above its mouth and half a mile from the wellknown Indian camp-site at Lower Black's Eddy. The work of carefully clearing out one of the depressions and trenching its refuse heap was begun yesterday afternoon and will occupy an indefinite time.

Notched in the slope whose angle is about 35 degrees, the depression, one of eight or nine others, fronts a solid ledge of argillite (an outcrop of the large vein here traversed and exposed by Gaddis' Run, and twice tapped near by, by modern quarries as the purest source of the material).

Its largest diameter is about thirty feet, its depth five, and breadth eight. The trench begun across its narrowest width, penetrating for three feet through loose yellow mould, has shown as yet nothing of importance beyond two bits of charcoal and broken (quartzite pebble) hammer-stones at a depth of one and one-half feet. Another excavation about three feet in diameter has entered the mass of refuse for four feet without reaching its bottom, and discovered at various points thirty-three "turtlebacks," twenty-five broken bases or points, and four hammerstones. On the surface about the other pits I gathered in a few hours twenty "turtlebacks," six ends or points, and fourteen hammer-stones.

With the work of penetrating to the bottom of the refuse, and studying the ancient quarrying process scarcely begun, I have hardly had time to more than think of the important questions suggested: Who made and worked the quarry? Will it show a successive series of occupations? Can it be connected with the village site at Lower Black's Eddy? What shall we say of these rudely chipped forms? Are they "wasters" and do they of all "wasters" yet heard of, resemble the Trenton specimens?

We are twenty-five miles above Trenton and at the largest and purest outcrop of argillite on the right river bank above that place. ${ }^{1}$ The bed of Gaddis' Run and the river-shore below its mouth are thickly strewn with argillite blocks and water-worn boulders - a pathway, in fact, littered with blade material, extending, from the ledge above referred to, to the Indian camp half a mile distant. While the significance of this has been obscured by chipped fragments from the modern quarries fallen into the stream, and the stone dressing that has accompanied the building of a dam, two bridges, and a canal aqueduct, there can be little doubt that the inhabitants of the village often went no farther than a few hundred yards along these beaches for their material.

But too much hangs upon the further examination of this site and the neighboring camp, now at last unfolded to the student in its fuller significance, to warrant a premature word.

\section{LETTERS TO THE EDITOR.}

$*^{*} *$ Correspondents are requested to be as brief as possible. The voriter's name is in all cases required as proof of good faith.

On request in advance, one hundred copies of the number containing his communication will be furnished free to any correspondent.

The editor will be glad to publish any queries consonant with the character of the journal.

\section{Science Work at the Avalon Summer Assembly.}

I HAVE just received a little blue pamphlet containing the announcement of the new summer school at Avalon, New Jersey, and an extremely interesting and suggestive address on "Science Teaching in the Schools," by Dr. Charles Dolley, its president. Copies of this, I have been told, may be had by writing to Mr. Charles Adamson, secretary, 119 S. 4th Street, Philadelphia, Pa. The objects and methods of this new school are so new and attractive that it certainly marks the beginning of a new era in the teaching of science and art in our common schools.

The keynote of Dr. Dolley's address is struck by the following sentences in speaking of the proper method of educating the coming generation: "They begin by moulding little birds' nests of clay, or constructing cones and cylinders, cubes, and octagons out of paper, without ever having examined a bird's nest, other than that of the sparrow under the eaves, and knowing absolutely nothing of the interest to be found in a prism of quartz, a snowflake, or an icicle. They have been taught of the distribution of whales and camels and all sorts of exotic varieties, but are absolutely ignorant and blind to the wonders of nature to be found at their very doors; wonders requiring no text-books, no costly instruments, but which may be investigated by means as simple and inexpensive as the key and kite string of Franklin."

How few the teachers, let me add, who have the slightest inkling as to the wonderful history written in the chalk or slate they daily use!

Missions and philanthropic societies do good work in this world, but much is wasted. " What is needed," says Dr. Dolley, " is a sanitary missionary in every home, and this we can secure by training the children, by awakening in their minds a desire for something better, for more sunshine, more flowers, a wider horizon and more wholescme surroundings." How few the housekeepers who know the slightest whit about the yeast they use, the mother and flowers of vinegar, the moulds on jellies, the cause of rancid butter, or the nature of contagion! "The tritest things of our mortal experience are the most mysterious." There is enough of interest in a mucilage bottle to keep a man studying a lifetime.

1 On Dark Hollow Run (below New Hope) I found a small vein of it nearly two miles from the river. The blue slate in Pidcock's Creek, on the south slope of Bowman's Hill and at the Harvey and Van Hart quarries below Taylor'sville, lacks the concholdal fracture. 
The above quotation is the tenor of that admirable article which ought to be read by every person interested in education and the welfare of his children and country.

Children are born with a love for nature which usually later leaves them. They are of an inquisitive turn of mind and admire flowers and birds while very young, but this is soon smothered instead of being fostered by text-book work and the common method of poking facts into reluctant brains in an ill-ventilated schoolroom by a teacher who knows all about the recent advances in pedagogy but nothing about the subject he is teaching.

The training of the senses of observation, of the faculty of reflection, and of the using of the hand, constitutes an education. One thus trained can get ten times more out of life than the bookworms who feed on second-hand facts.

The students - and the very youngest students - must be reached, and the manner of reaching them is through the teachers. For this purpose the new summer school at Avalon has been established. The work in natural history will be mostly out-ofdoors. The students will go with the teachers out among the dunes. in boats about the bays and thoroughfares, among the marshes and along the shore, gathering plants and animals for study. The students in art will sketch right out among the bright-colored sand dunes and study the richness of color which characterizes those beaches and marshes by the sea.

Dr. Charles Dolley is the president and leading founder of this institution. He was formerly Professor of General Biology in the University of Pennsylvania. He was long a student and near friend of Dr. Joseph Leidy, whom, in his character and broadness of views, he resembles. He is a close student of nature, versed in both languages and science, and possessed of such personal magnetism and pleasing manners that he is always surrounded by many friends and admirers who are always helped by his neverfailing enthusiasm and encouragement. A better person could not have been chosen for such a position.

The place selected for this summer school is a good one. Plenty of good material for science work is near at hand. It is the only beach on the coast where beautiful forests of red cedar and holly are still standing. There is a long even beach, unexcelled for bathing and carriage and bicycle riding. There are high white sand dunes and beyond vast stretches of salt marshes intersected by many bays, thoroughfares, and salt ponds. On the mainland there are forests of pines and many beautiful plants peculiar to the "low pine barrens of south Jersey."

For a sum not exceeding $\$ 50$, including all expenses, a teacher can spend five weeks pleasantly and profitably at the seashore, not only bathing and enjoying the salt sea air and the other pleasures of such a result but breathing in a kind of knowledge which they will relish and impart to those under them and thus help to bring about this change in the manner of common school education for which many are hoping.

Swarthmore, Pa.

Early Man in Minnesota.

IN The American Geologist (April, 1893) Mr. Wm. H. Holmes has published another long article, this time endeavoring to show that there is no evidence whatever of the existence of early man in Minnesóta. The article is very prettily illustrated with fanciful sketches, which Mr. Holmes's practice as an artist makes him to evolve from his inner consciousness, and which he employs in all his writings in place of arguments in support of his theory of the non-existence of palæolithic man in North America.

He says that " Besides the investigations of Professor Wincheli and Miss Babbitt, no work has been done upon the archæology of this region, although other writers, notably Mr. Warren Upham, Professor G. F. Wright, and Mr. Henry W. Haynes, taking for granted the correctness of all the original observations and conclusions, have ventured to enlarge upon the material published."

The only "venturing" I have done has been to express to the late Miss Babbitt, who sent to me for examination a large quantity of pieces of quartz collected by herself, the conviction that these fragments were of artificial and not of natural origin. As Mr. Holmes calls them Indian refuse, I can scarcely be charged with very hazardous venturing. Miss Babbitt wrote to me that she had discovered them in undisturbed deposits of glacial origin. If this is true, as I have no reason to doubt it is, certain objects among them presenting the palæolithic type must of necessity be true palæolithic implements, and not, like many of a similar type that have been found on the surface, be of doubtful origin. Every one knows that such objects are also sometimes found in Indian shell-heaps and village sites. Accordingly, whether any particular object can be positively identified as a true palæolithic implement or not depends upon the conditions of its occurrence. That is a question for geologists to answer, and if they pronounce the site to be of glacial origin the probability is very great that similar objects found in the immediate vicinity are also palæolithic implements. This is the state of the question with respect to the objects found in the Trenton gravels. How does this reasoning apply to the so-called Babbitt quartzes? The glacial man in fashioning palæolithic implements must have produced a great many splinters and fragments, just as the Indian did in producing his implements. If any particular locality offers only one available material to work with, the ref use of palæolithic man and of the Indian must be precisely alike. I understand this to be true of the out-cropping of veins of quartz in the slate in the neighborhood of Little Falls, Minnesota. No one doubts that Indian relics are found in that vicinity, as is always the case at all good fishing sites like that. But Indian implements and palæolithic implements are very different in appearance, and no skilled archæologist will mistake one for the other. I have seen palæolithic implements that Miss Babbitt said she had found in undisturbed glacial deposits. This is positive, undisputed testimony. What has Mr. Holmes to say in answer to it? I will quote his words precisely: "My investigations have shown that the glacial quartzes were probably not originally included in the loam but rather that they were introduced into it in post-glacial times, and that they were rude because mere shop refuse, the period of occupation thus, in all probability, corresponding to that of our historic aborigines." This may be very convincing to some people, but to my mind it is not quite satisfactory. Professor Winchell says that the quartz fragments are to be found over a very extensive region, "up and down the river an unknown distance," and extending "downward three or four feet" in "hard-pan drift containing boulders." That is something quite different from "loam," the word persistently employed by Mr. Holmes in speaking of the fragments. Loam is defined by Webster as meaning "a mixture of clay and sand with organic matter to which its fertility is chiefly due." If this is the nature of "hard-pan drift, containing boulders," I am incapable of understanding ordinary language. Professor Winchell's words can only be understood of undisturbed glacial deposits. But Mr. Holmes says "there is nothing in the conditions and phenomena of the site that will enable us to say whether the beginning of the quartz-working dates back one hundred or one thousand years." He reaches this sweeping conclusion by imagining that Indian refuse from the surface has been introduced into this "hard-pan" by sinking through the decasing substance of the roots of large trees that have been uprooted by a tornado. Let me quote his own words: "The explanation thus furnished of the distribution of the worked quartzes of this locality through the glacial deposits to the depth of four feet or more is so satisfactory that no other theories are called for, and little further discussion seems necessary." To my mind this explanation is just as satisfactory, and no more so, than Mr. Holmes's former explanation that "most of the so-called gravel implements of Europe are doubtless the $r$ jects of manufacture."

Mr. Holmes first draws pretty pictures, and then draws from them the conclusion that " the record may be so altered in the period of a generation as to be read ten thousand years instead of fifty. Such is the magic of Nature's transformations, and such are the pitfalls set for unwary explorers." Miss Babbitt, the "unwary explorer" in the present instance, is no longer living to defend herself from such assumption as this, but I think all lovers of justice will feel that this is a pretty weak answer to her positice assertions. Mr. Holmes continues: "The mistakes made by Miss Babbitt are precisely such as others have made through taking 